\title{
The Crisis of the Inner City
}




\section{The Crisis of the Inner City}

Edited by

Martin Loney

and

Mark Allen 
(c) Mark Allen, Ron Bailey, Bob Davis, Judith Green, Bill Jordan, Martin Loney, Alex Lyon, Marjorie Mayo, Jef Smith, Robin Thompson, Andrew Thornley, John Tilley, Peter Walker, Jean Whitfield 1979

Softcover reprint of the hardcover 1st edition 1979

All rights reserved. No part of this publication may be reproduced or transmitted, in any form or by means, without permission.

First published 1979 by

THE MACMILLAN PRESS LTD

London and Basingstoke

Associated companies in Delhi Dublin

Hong Kong Johannesburg Lagos Melbourne

New York Singapore and Tokyo

British Library Cataloguing in Publication Data

The crisis of the inner city.

1. Cities and towns-Great Britain

2. Great Britain-Social conditions-1945-

I. Loney, Martin II. Allen, Mark

309. 1'41

HT133

ISBN 978-0-333-25691-6

ISBN 978-1-349-16163-8 (eBook)

DOI 10.1007/978-1-349-16163-8

This book is sold subject to the standard conditions of the Net Book Agreement.

The paperback edition of this book is sold subject to the condition that it shall not, by way of trade or otherwise, be lent, resold, hired out, or otherwise circulated without the publisher's prior consent in any form of binding or cover other than that in which it is published and without a similar condition including this condition being imposed on the subsequent purchaser. 


\section{Contents}

Preface

Notes on Contributors

vii

Introduction

MARTIN LONEY

Part 1

THE POLITICAL FRAMEWORK

1 A Conservative View PETER WALKER

2 A Labour View ALEX LYON

3 A Marxist View 32 BOB DAVIS and JUDY GREEN

\section{Part 2}

\section{LOCAL GOVERNMENT}

4 The Inner City Partnerships: a Critical Assessment 57 JOHN TILLEY

5 The Social Services and the Inner City 70 JEF SMITH

6 The Planner as Catalyst 80

ROBIN THOMPSON and ANDREW THORNLEY

Part 3

COMMUNITY PERSPECTIVES

7 Housing for People RON BAILEY 
vi Contents

8 Claimants in Action JEAN WHITFIELD in collaboration with BILL JORDAN

9 Radical Politics and Community Action MARJORIE MAYO

Conclusion: Radical Reconstruction MARTIN LONEY

Notes and References 


\section{Preface}

In inviting contributions to this volume the editors have been concerned to provide a variety of perspectives on what is popularly termed the inner city crisis. In particular the volume is addressed not simply to students and academics but also, and primarily, to practitioners. It is directed at those who as politicians, administrators, professionals or activists make, implement or oppose policies which affect the inner city.

Our concern is to clarify both the nature of the inner city crisis and the kinds of responses which are open. The solutions must be found by those who live and work in the inner city, and it is ultimately their strength and their ability to fight for decent conditions which will determine the outcome. We hope this volume will, in some small measure, be of assistance.

We would like to thank Carol Johns for her help in preparing the manuscripts for the publishers.

December 1978

M. L.

M. A. 


\section{Notes on Contributors}

MARK ALLEN is Editor in Chief of Community Care and Editor of Nursing Mirror.

RON BAILEY has worked in the housing field since 1965. $\mathrm{He}$ is currently working for the Housing Emergency Office. His publications include The Squatters (Penguin, 1973) and The Homeless and the Empty Houses (Penguin, 1977). He wrote The Grief Report for Shelter in 1972.

BOB DAVIS worked as a Research Fellow at Newcastleupon-Tyne Polytechnic and the North Tyneside Community Development Project from 1973-8. He is currently employed as a community worker at the Walker Resource Centre, Newcastle-upon-Tyne.

JUDITH GREEN was a Research Fellow with the University of Durham and the Benwell (Newcastle) Community Development Project from 1974-8. She is currently employed as a local government research officer.

BILL JORDAN is a Lecturer in Social Work at Exeter University and a part-time social worker at Exe Vale Hospital, Exeter. His publications include Paupers (Routledge and Kegan Paul, 1973) and Poor Parents (Routledge and Kegan Paul, 1974). 


\section{x Notes on Contributors}

MARTIN LONEY lectures in Social Policy at the Open University. He has served as Director of Research for World University Service in Geneva and as General Secretary of the National Council for Civil Liberties. His previous publications include Rhodesia: White Racism and Imperial Response (Penguin, 1975).

ALEX LYON, MP, has represented York since 1966. He was Minister of State at the Home Office, 1974-6.

MARJORIE MAYO works with the Joint Docklands Action Group. She previously worked with the Community Development Project central research team and lectured at the University of Surrey. She has published extensively on community work and edited Women in the Community (Routledge and Kegan Paul, 1977).

JEF SMITH is Director of Social Services for Kingstonupon-Thames. His articles have appeared in New Society, Community Care and Social Work Today.

ROBIN THOMPSON is Deputy Borough Planning Officer for the London Borough of Greenwich. He has worked at the Centre for Environmental Studies and the Architectural Association and is a council member of the Royal Town Planning Institute.

ANDREW THORNLEY lectures in Planning at the Polytechnic of Central London. His publications include Theoretical Perspectives on Planning Participation (Pergamon, 1977).

JOHN TILLEY, MP, represents Lambeth Central. He was formerly council leader in the London Borough of Wandsworth.

PETER WALKER, MBE, MP, has represented Worcester since 1961. He became the first Secretary of State for the Environment in 1971, and subsequently served as Secretary of State for Trade and Industry. His recent publications 
Notes on Contributors xi

include The Ascent of Britain (Sidgwick and Jackson, 1977).

JEAN WHITFIELD grew up in South-east London and is now an unemployed married woman. She is a member of the Plymouth Claimants Union. 